
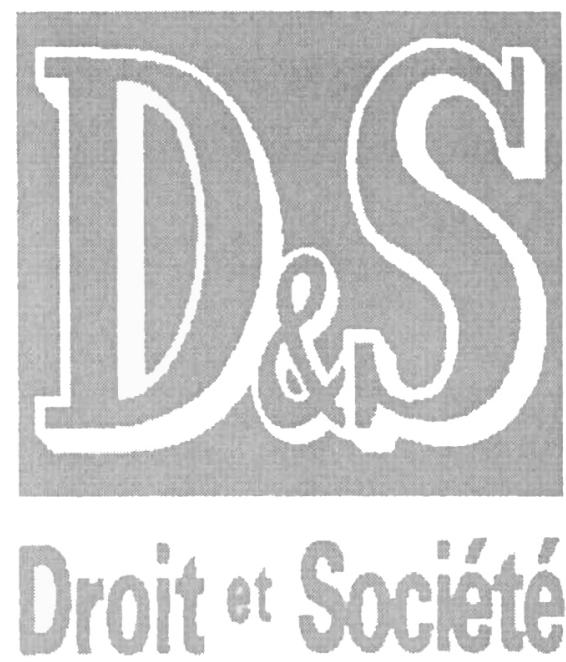

Revue publiée avec le concours du Centre National de la Recherche Scientifique (France)

\section{ISSN 0769-3362}

\section{Administration ef abonnements \\ Librainie Générale de Droit et de Jurisprudence, \\ 31, rueFalguière \\ F-75741 Paris Cedex 15 \\ Tél.:01.56.54.16.00 Fax:01.56.54.16.49}

\section{Secrétariat de rédaction}

Ressource pourla Recherche Justice,

54 , rue de Garches, F-92420 Vaucresson

e-mail: lesavre@ext.jussieu.fr

Tél: 01.47.95.98.66 Fax:01.47.01.41.48

Au sommaire du numéro 41-1999

\title{
Dossier:
}

L'emploi, l'entreprise : nouvelles normes, nouvelles règles coordonné par Guy Groux

Guy Groux : Présentation

Jens Thoemmes : La construction du temps de travail: normes sociales ou normes juridiques?

Guy Groux : L'entreprise : conflits et régulation(s)

Thiery Vedel : De la régulation intemalisée à la régulation externalisée dans le domaine des télécommunications

Claude Didry: Regands sur l'Europe. Une lecture de l'ouvrage dirigé par Alain Supiot: "Audelà de l'emploi. Transformations du travail et devenir du droit du travail en Europe"

Loìc Cadin : Le marché du travail: règles et normes de carrière. Une comparaison internationale France/Nouvelle-Zélande

\section{Etudes}

François Rigaux : L'opacité du fait face à l'illusoire limpidité du droit

Ira Deryckere: The Family Assembly and the Justice of the Peace in 19th Century Flanders Marcelo Neves : Entre sous-intégration et sur-intégration: la citoyenneté inexistante dans les pays de la modemité périphérique

\section{Et la rubrique Chronique bibliographique}




\section{CANADIAN JOURNAL OF LAW AND SOCIETY REVUE CANADIENNE DROIT ET SOCIÉTÉ}

The Journal has existed since 1985. Founded by Rainer Knopff, with the assistance of Ann Griffith. it was initially hased in the Research Unit for Socio-Legal Studies of the University of Calgary. Since June 1990, it has been affiliated with the Canadian Association of Law and Society. Its edjtorship was then transferred to the Université du Québec à Montréal, so as to commence the rotation of this function among different Canadian universities. Thanks to the financial support of the Université du Québec à Montréal, as of the transfer the Journal became a biannual review beginning with Volume 7 (1992), and certain issues are devoted to specific themes. The Canadian Journal of Law and Soriety seeks the promotion and publication of research on law and legal systems understood as social phenomena. The Journul is interdisciplinary, calling for diverse methods of analysis and perspectives on law.

The Journal was published by the University of Calgary Press up to Volume 9. \#I and is now published at the Université du Québec à Montréal. It is funded by the Social Sciencen and Humanities Research Council of Canada and the Université du Québec à Montréal.

The Jeurnal is indexed in the Corpus Almanac \& Canadian Sourcebook: the Standard Periodical Directory; the Oxbridge Data Center; the Canadian Periodical Index: Ulrich's International Periodicals Directory: Dustbooks/The International Directory of Little Magazines and Small Presses; the Index to Canadian Legal Periodical Literature; WESTLAW: the Index to Legal Periodicals: Sociological Abstract: Current Legal Sociology; Criminal Justice Abstract: Felix Dietrich Verlag GmbH \& Co KG. IBZ-International Bibliography for Periodical Literature: Novaya Literatura po Sotsialistnym i gumanitarnym naukam, Gosudarstvo i Pravo (New Literature in the Social and Humanitarian Sciences, Government and Truth).

The index of all articles, comments. and review cssays is published in Volume 12 \# (1997).

Instructions to authors are detailed on page 197.

$* * * * * * * *$

La Rev'uc existe depuis 1985. D'abord installée à The University of Calgary, auprès du Research Unit for Socio-Legal Studies, Faculty of Social Sciences, elle a été créée par Rainer Knopff assisté de Ann Griffith. Depuis juin 1990, la Rel'ue est rattachée à l'Association canadienne Droit et Société et la rédaction a été transférée à l'Université du Québecc à Montréal. de façon à en permettre la rotation dans les différentes universités canadiennes. Grâce à l'appui financier de l'Université du Québec à Montréal, elle devient. avec ce transfert, une revue bi-semestrielle à partir du Volume 7 (1992) et certains numéros sont thématiques. La Revue canadienne Droit et Société vise à promouvoir la publication des recherches portant sur le droit et les systèmes juridiques, entendus comme phénomènes sociaux. La Revue est interdisciplinaire, faisant appel aux diverses perspectives et méthodes d'analyse du droit.

La Rev'ue a été publiée par University of Calgary Press jusqu'au Volume 9 \#1. Elle est maintenant publiée à l'Université du Québec à Montréal. Elle est subventionnée par le Conseil des recherches en Science humaines du Canada et par l'Université du Québec à Montréal.

La Reive est répertoriée dans Corpus Almanac \& Canadian Sourcebook: Standard Periodical Directory: Oxbridge Data Center: Canadian Periodical Index; Ulrich's International Periodicals Directory: Dustbooks/The International Directory of Little Magazines and Small Presses; Index to Canadian Legal Periodical Literature; WESTLAW: Index to Legal Periodicals; Sociological Abstract: Current Legal Sociology: Criminal Justice Abstract: Felix Dietrich Verlag GmbH \& Co KG. IBZ - International Bibliography for Periodical Literature: Novaya Literatura po Sotsialistnym i gumanitarnym naukam, Gosudarstvo i Pravo (New Literature in the Social and Humanitarian Sciences, Government and Truth).

L'index de tous les articles. commentaires et notes critiques est publić dans le Volume 12 \#2 (1997).

Les recommandations aux auteurs pour la soumission des manuscrits se trouvent à la page 198. 
Dorothy Harley Eber, Images of Justice. A Legal History of the Northwest Territories as Traced through the Yellowknife Courthouse Collection of Inuit Sculpture Janice Dickin

Tom Coffman, Nation Within: The Story of America's Annexation of the Nation of Hawai ${ }^{i}$.

Damien P. Horigan

Hillary Sommerlad and Peter Sanderson, Gender, Choice and Commitment: Women Solicitors in England and Wales and the Struggle for Equal Status Gisela Shaw

All manuscripts should be sent to the Editor at the following address:

Les manuscrits doivent etre envoyés à l'attention du directeur de la Revue à l'adresse suivante:

Departement des Sciences juridiques Université du Québec à Montréal C.P. 888, succursale Centre-ville Montréal, Québec, Canada, H3C 3P8 TÁ.: (514) 987-3000, poste 4712* FAX: (514) $987-6548$

E-mail/Courriel: murbach.ruth ( uqam.ca
Please address all subscription orders and change of address to:

Pour les abonnements et les changements d'adresse, veuillez écrire à l'adresse ci-dessous:

Service des publications Université du Québec à Montréal C.P. 8888, succursale Centre-Ville Montréal, Québec, Canada, H3C 3P8 Té.: (514) 987-3000, poste 4229\#

FAX: (514) \$87-0307

Internet: http://ww.juris.uqam.ca/rcds/index.htm 